\title{
Factors Affecting Stock Prices in India: A Time Series Analysis
}

\author{
Arpit Bhargava ${ }^{1}$ Ankush Bhargava ${ }^{2}$ Surbhi Jain ${ }^{3}$ \\ ${ }^{1}$ Student, Master of Science in Economics, TERI University, Delhi -110070, \\ ${ }^{2}$ Assistant Professor, Commerce Department, Zakir Husain Delhi College Evening (University of Delhi), \\ Jawaharlal Nehru Marg, New Delhi-110002. \\ ${ }^{3}$ Chartered Accountant
}

\begin{abstract}
The research has been undertaken to study the relationship between macro variables such as Inflation, Index of Industrial production(IIP), Money Supply, Oil prices, Exchange rates, Gold prices and Gross domestic product (GDP) and Stock Prices using time series regression. The sample of the study consists macro variables and stock prices for the period 2004-2013 on quarterly basis. The study revealed that only Exchange Rate, Oil Prices and Inflation have significant impact over Stock prices.Further we observed that Exchange Rate and Inflation are negatively related to Stock prices and Oil prices are positively related. Another interesting result that we observe is that gold price does not have any major impact over the stock prices.
\end{abstract}

Keywords: Stocks, Time Series Data,Macro Variables, Unit Root Test

\section{Introduction}

Stock market is an organized financial market where brokers and traders buy and sell stocks, bonds and securities. It is an interconnected system which delivers conditions appropriate to exchange securities, convert real assets into financial assets in order to raise funds from the market. Thus it has multiple purposes to serve. Thus it facilitates capital expansion by companies via selling shares, channelizing savings, and increasing companies' profits.Considering Indian stock market, it is one the oldest in Asia. There are two stock exchanges in India i.e. National Stock Exchange (N.S.E.) and Bombay Stock Exchange (B.S.E.). National Stock exchanges incorporated 1992 and Bombay Stock exchange in 1875. Major trading is done in NSE and thus it is in the leading position.

Paper studies the relationship between different factors determining the stock prices in Indian Stock market. A time series regression with independent variables as Inflation, Index of Industrial production(IIP), Money Supply, Oil prices, Exchange rates, Gold prices and Gross domestic product (GDP) and stock prices as dependent variable is run in order to validate if these variables are statistically significant in explaining the behavior of stock prices in Indian market or not.

This paper is in the following order: Section II provides information about the literatures that are present, Section III talks about the methodology that has been undertaken in the paper, objective and hypothesis, Section IV is the regression results section and Section V concludes about the findings.

\section{Literature}

There has been substantial literature present where it has been shown that macro as well as micro variables are significant in explaining the behavior of stock prices. Nelson (1976) took data of the period 19531994 and established a negative relationship between stock returns and expected as well as unexpected inflation for US economy. Apergis and Eleftheriou (2002) did a case study on Athens stock market where they took data for the period 1988-1999 and it was found that there was a continuous decline in the inflation and a rise in stock prices. Another study by Fama and Schwert (1977) for the period 1953-1971 showed that return on common stocks were negatively correlated with expected as well as unexpected inflation in US.

Jamil and Ullah (2013) used co-integration technique to test if there is a relationship exists between stock prices and exchange rate for Pakistan economy. Data for the period 1998-2009 was analyzed which established the result that there is a relation between the variables at-least in short run. Abdalla and Murinde (1997) investigated in financial markets of different countries like India, Pakistan, Korea and Philippines. They found out that there exists a one-way relationship between exchange rate and stock prices. They recommended that government should use exchange rate policies very cautiously since it has impact over stock market of the given economy.

Park and Ratti (2008) did a regression analysis taking US and other 13 European economies and after considering the data for 1986-2005 showed that Norway had positive relation between stock returns and oil prices. Increases in oil price causes stocks' return to depress. Stock prices are both negatively and positively related with oil prices depending upon the fact whether a country is oil importing country or oil exporting country. Cheung and NG (1998) studied the relationship between stock prices and real oil price, consumption 
expenditure, money supply and GNP across different countries using Johansen co-integration technique and established the result that there is an association between these variables and stock prices.

Chen, Roll and Ross (1986) tested the risk and reward in stock market associated with six major variables i.e. short term and long term interest rates, inflation, high-low grade bonds and industrial production. It was found that these variables significantly explained the stock markets returns. Mukherjee and Naka (1995) studies Japanese stock returns and macroeconomic variables using VECM (vector error correction model). It was found that stock market was co-integrated with the six dependent variables.

Homa and Jaffee (1971) showed econometrically that there is significant systematic association between stock market and money supply. Rudolph (1972) used weekly data and established a noticeable result of the relationship between money supply and stock prices (SP) where SP included 500 poor and standard stock indexes.

Al-Sharkas(2004) studied relationship between stock prices and macro-economic variables including money supply for the period of 1998-2008. According to the results, Turkish Stock prices was positively associated with foreign transactions and inversely related to interest rates. Mock (1993) verified that there was a unidirectional causality between interest rates and closing stock prices using ARIMA approach and Granger Causality tests.

\section{Methodology}

Hypothesis: To test whether IIP, WPI, GDP, Money supply, Exchange rate, Oil prices and Gold Prices can explain changes in Stock prices or not i.e.

$\mathrm{H} 0: \mathrm{IIP}=\mathrm{WPI}=\mathrm{GDP}=$ Money supply $=$ Exchange rate $=$ Oil prices $=$ Gold Prices $=0$

H1: At-least one of the variables $\neq 0$

Data on variables has been collected from RBI, MOSPI and NSE India for the period 2004-2013 on quarterly basis. A time series simple linear regression is run where dependent variable is stock price (Nifty500 Index) and independent variables are IIP (Index of Industrial production with 2004-05 base year), WPI (Whole Sale Price Index with 2004-05 base year), GDP (Gross Domestic Product at factor cost at constant price 200405), Money supply (M1), Exchange rate (₹/\$), Oil Prices(\$/Barrel) and Gold Prices(\$/troy ounce).Initial regression model is as follows

Stock prices $=\beta_{0}+\beta_{1}$ IIP $+\beta_{2}$ WPI $+\beta_{3}$ GDP $+\beta_{4}$ Money Supply $+\beta_{5}$ ExchangeRate $\quad+\beta_{6}$ Oil Prices $+\beta_{7}$ Gold prices $+\varepsilon_{\mathrm{i}}$

The main purpose of the study is to test whether the variables that are found significant in the literature, also holds true forIndian Stock Marketor not i.e. if there exists a causal relationship between dependent and independent variables or not?

\section{Findings}

Basic assumption before starting any time series regression model is stationary assumption. Stationarity means that joint probability distribution does not change with time period. In other words, we can think of it as variables' properties like mean variance, autocorrelation etc. do not change with the shift in time period. We checked for stationarity using Phillips Perron test and we found that exchange rate, oil prices and gold prices are not stationary. Thus we used first differencing method and converted these variables into stationary variables. New regression model is as follows

Stock prices $=\beta_{0}+\beta_{1}$ IIP $+\beta_{2}$ WPI $+\beta_{3}$ GDP $+\beta_{4}$ Money Supply $+\beta_{5} \Delta$ Exchange Rate $+\beta_{6} \Delta$ Oil Prices $+\beta_{7} \Delta$ Gold prices $+\varepsilon_{\mathrm{i}}$

Before regressing over the variables we look at the summary statistics (Table 1).

\begin{tabular}{|l|l|l|l|l|}
\hline Variables & Mean & Standard Deviation & Min & Max \\
\hline Nifty $(\%)$ & 3.586543 & 12.67355 & -32.07958 & 42.5605 \\
\hline IIP $(\%)$ & 1.814259 & 4.953656 & -9.883257 & 8.758004 \\
\hline WPI $(\%)$ & 6.62087 & 2.555559 & .5442643 & 11.01536 \\
\hline GDP $(\%)$ & 1.999713 & 6.220622 & -7.663677 & 13.80635 \\
\hline Money $(\%)$ & 3.328172 & 2.672309 & -1.323493 & 9.064741 \\
\hline$\Delta$ Exchange $(₹ / \$)$ & .5197143 & 2.031672 & -2.97 & 6.18 \\
\hline$\Delta$ Oil Prices (\$/Barrel) & 1.295429 & 13.69928 & -59.14 & 25.98 \\
\hline$\Delta$ Gold Prices (\$/troy ounce) & 24.71714 & 81.10029 & -214.12 & 195.34 \\
\hline
\end{tabular}

Table 1 
Next step is to check about the associations between these variables. This is represented in the correlation matrix given in table 2.

\begin{tabular}{|c|c|c|c|c|c|c|c|c|}
\hline & Nifty (\%) & $\operatorname{IIP}(\%)$ & $\begin{array}{l}\Delta \text { Gold Prices } \\
\text { (\$/troy ounce) }\end{array}$ & $\begin{array}{l}\text { Money } \\
(\%)\end{array}$ & $\begin{array}{l}\Delta \text { Exchange } \\
(₹ / \$)\end{array}$ & $\begin{array}{l}\Delta \text { Oil Prices } \\
(\$ / \text { Barrel })\end{array}$ & WPI (\%) & $\begin{array}{l}\text { GDP } \\
(\%)\end{array}$ \\
\hline Nifty (\%) & 1 & & & & & & & \\
\hline IIP $(\%)$ & 0.2097 & 1 & & & & & & \\
\hline WPI (\%) & -0.6553 & -0.1481 & 1 & & & & & \\
\hline GDP $(\%)$ & 0.1128 & 0.7225 & -0.0544 & 1 & & & & \\
\hline Money (\%) & 0.2674 & 0.3696 & -0.2949 & 0.1649 & 1 & & & \\
\hline$\Delta$ Exchange $(₹ / \$)$ & -0.5977 & -0.3231 & 0.2722 & -0.0866 & -0.2896 & 1 & & \\
\hline $\begin{array}{l}\Delta \text { Oil } \\
(\$ / \text { Barrel })\end{array}$ & 0.5023 & 0.0642 & -0.2407 & -0.2411 & 0.1181 & -0.3504 & 1 & \\
\hline $\begin{array}{l}\Delta \text { Gold Prices } \\
(\$ / \text { troy ounce })\end{array}$ & 0.2162 & 0.2317 & -0.0028 & 0.1815 & 0.1436 & -0.4702 & 0.1414 & 1 \\
\hline
\end{tabular}

Table 2

The above correlation matrix suggests that three variables namely WPI, $\Delta$ Exchange Rate and $\Delta$ Oil Prices provide good explanation for changes in stock prices (NIFTY). $\Delta$ Gold prices, money supply and IIP have moderate correlation with NIFTY. Current GDP has weak correlation with NIFTY. Thus we can suspect that WPI, $\Delta$ Oil prices and $\Delta$ Exchange rate could have a significant impact over NIFTY. Initial regression is run using all the variables mentioned in the study. We start eliminating insignificant variablesand again regression is run with remaining exogenous variables considering the fact that there is no causal relationship exists between the eliminated variables and other independent variables. This step wise elimination of variables in given in table 3. Results show that only three variables explain stock prices at 5\% significance level. These variables are $\Delta$ Exchange rate, $\Delta$ Oil Prices and WPI.

\begin{tabular}{|l|l|l|l|l|l|l|l|}
\hline & IIP (\%) & $\begin{array}{l}\Delta \text { Gold Prices } \\
(\$ / \text { troy ounce) }\end{array}$ & Money (\%) & $\begin{array}{l}\Delta \text { Exchange } \\
(₹ / \$)\end{array}$ & $\begin{array}{l}\Delta \text { Oil Prices } \\
(\$ / B a r r e l)\end{array}$ & WPI (\%) & GDP (\%) \\
\hline Nifty (\%) & $\checkmark$ & $\checkmark$ & $\checkmark$ & $\checkmark$ & $\checkmark$ & $\checkmark$ & $\checkmark$ \\
\hline Nifty (\%) & $\checkmark$ & $\checkmark$ & & $\checkmark$ & $\checkmark$ & $\checkmark$ & $\checkmark$ \\
\hline Nifty (\%) & & $\checkmark$ & & $\checkmark$ & $\checkmark$ & $\checkmark$ & $\checkmark$ \\
\hline Nifty (\%) & & & $\checkmark$ & $\checkmark$ & $\checkmark$ & $\checkmark$ \\
\hline Nifty (\%) & & & $\checkmark$ & $\checkmark$ & $\checkmark$ & \\
\hline
\end{tabular}

Table 3

Regression results (table 4) show that changes in exchange rate is negatively related to stock prices. For example, an increasingcurrency depreciation would cause larger fall in stock prices. Similar sign is attached with country's inflation with stock prices i.e. more inflation a country is experiencing; more will be the tendency of stock prices to fall. Oil prices are positively impacting the stock prices in India.

\begin{tabular}{|l|l|l|l|l|}
\hline nifty & Coefficients & Standard Error & $\mathrm{t}$ & $\mathrm{P}>\mathrm{t}$ \\
\hline$\Delta$ Exchange & -2.37363 & 0.623549 & -3.81 & 0.002 \\
\hline$\Delta$ Oil Prices & 0.236582 & 0.116198 & 2.04 & 0.030 \\
\hline WPI & -2.45762 & 0.609099 & -4.03 & 0.000 \\
\hline Intercept & 20.98613 & 4.626595 & 4.54 & 0.000 \\
\hline
\end{tabular}

Table 4

All beta coefficients in the final regression model are significant at 5\% significance level. As joint Ftest is considered i.e. 21.33 (Table 5), it is also significant at $1 \%$ significance level. Coefficient of determination is $67.37 \%$ (Table 5) which means there is good causal relationship exists between these variables.

\begin{tabular}{|l|l|l|l|}
\hline Source & SS & d.f. & MS \\
\hline Model & 3782.209 & 3 & 1260.736 \\
\hline Residual & 1831.899 & 31 & 59.09351 \\
\hline Total & 5614.108 & 34 & 165.1208 \\
\hline
\end{tabular}

Table 5

\begin{tabular}{|l|l|l|}
\hline No.of observations & $=$ & 35 \\
\hline $\mathrm{F}(3,31)$ & $=$ & 21.33 \\
\hline Probability> F & $=$ & 0.000 \\
\hline R-squared & $=$ & 0.6737 \\
\hline Adjusted R-squared & $=$ & 0.6421 \\
\hline Root MSE & $=$ & 7.6872 \\
\hline
\end{tabular}

Table 6 
We observe that these three variables significantly explain variations in stock prices in India. But whether these beta coefficients are consistent or not depends upon whether there is perfect multicollinearity exists between the independents variables or not. We calculated Variance Inflation Factor in table 7 for testing the presence of multicollinearity. From the results, we can infer that there is zero or very negligible cause and effect relationship between our independent variables which satisfies consistency condition for the beta coefficients. We also tested for heteroscedasticity using Breusch Godfrey pagan test and found no heteroscedasticity with any of the variables. Thus we can trust the t-statistics and R-squared variables associated with beta coefficients.

\begin{tabular}{|l|l|l|}
\hline Variable & VIF & 1/VIF \\
\hline$\Delta$ exchange & 1.19 & 0.839758 \\
\hline$\Delta$ oil & 1.17 & 0.854382 \\
\hline WPI & 1.11 & 0.901831 \\
\hline Mean VIF & 1.16 & \\
\hline
\end{tabular}

Table 7

\section{Conclusion}

We established that Exchange Rate, Oil Prices and WPI do have an effect over stock prices in India. Another interesting result that we observe is that gold price does not have any significant impact over the stock prices. Similar results have been found out in other literatures too. Finally, we reject the null hypothesis of all variables do not affect stock prices and can accept the alternate hypothesis i.e. there are some variables present in the model that do affectthe stock prices in India.

\section{References}

[1]. Nelson, Charles R. 1976. Inflation and Rates of Return on Common Stock. The Journal of Finance 31 (2): $471-83$

[2]. Apergis, Nicholas, and Sofia Eleftheriou. 2002. Interest rates, Inflation, and Stock Prices: The case of the Athens Stock Exchange. Journal of Policy Modeling 24 (3): 231-36.

[3]. Fama, Eugena F., and G. Willian Schwer. 1977. Asset Returns and Inflation. Journal of Financial Economics 5 (2): $115-46$.

[4]. Jamil, Maheen, and Naeem Ullah.2013. Impact of Foreign Exchange rate on stock prices. IOSR Journal of Business and Management 7 (3): 45-51.

[5]. Abdalla, Issam S.A., and Victor Murinde. 1997. Exchange rate and Stock Price Interactions in Emerging Financial Markets: Evidence on India, Korea, Pakistan and the Philippines. Applied financial Economics 7 (1): 25-35.

[6]. Park, Jungwook, and Ronald A. Ratti. 2008 Oil price shocks and stock markets in the U.S. and 13 European countries. Energy Economics 30 (5): 2587-608.

[7]. Cheung, Yin-Wong, and Lilian K.Ng. 1998. International evidence on the stock market and aggregate economic activity. Journal of Empirical Finance5 (3): 281-96.

[8]. Chen, Nai-Fu, Richard Roll, and Stephen A. Ross. 1986. Economic Forces and the Stock Market. The Journal of Business59 (3): 383-403.

[9]. Mukherjee, Tarun K., and Atsuyuki Naka. 1995. Dynamic Relations between Macroeconomic Variables and the Japanese Stock Market: An Application of a Vector Error Correction Model. Journal in Financial Research 18 (2): 223-37.

[10]. Homa, Kenneth E., and Dwight M. Jaffee. 1971. The Supply Of Money And Common Stock Prices. The Journal of Finance 26 (5): 1045-66.

[11]. Rudolph, J. Allan. 1972. Money Supply and common Stock prices. Financial Analysts Journal 28 (2): 19-25.

[12]. AL-Sharkas, A. 2004. The Dynamic Relationship between Macroeconomic Factors and the Jordanian Stock Market. International Journal of Applied Econometrics and Quantitative Studies 1 (1): 97-114.

[13]. Gupta, Jyoti P., Alain Chevalier, and Fran Sayekt. 2000. The Causality Between Interest Rate, Exchange Rate and Stock Price in Emerging Markets: The Case of the Jakarta Stock Exchange. EFMA 2000 Athens. 